\title{
Using a crop simulation model to select the optimal climate grid cell resolution: A study case in Araucanía Region
}

\author{
R. Orrego ${ }^{1}$, A. Ávila ${ }^{1,2}$, F. Meza ${ }^{3}$, F. Matus ${ }^{1,4^{*}}$ \\ ${ }^{1}$ Scientific and Technological Bioresource Nucleus, Universidad de La Frontera, Chile. ${ }^{2}$ Centro de Modelación \\ y Computación Cientifica, Universidad de La Frontera, Chile. ${ }^{3}$ Centro Interdisciplinario de Cambio Global. \\ Departamento de Ecosistemas y Medio Ambiente Pontificia Universidad Católica de Chile, Chile. ${ }^{4}$ Departamento \\ de Ciencias Químicas, Universidad de La Frontera,Chile. ${ }^{*}$ Corresponding author: francisco.matus@ufrontera.cl
}

\begin{abstract}
Crop models are sensitivi by the climatic spatial scale for performing thesimulation. Several crop simulation studies use mesoescale climate database $(20-50 \mathrm{~km})$, where topography is neglected. We develop a method to select the optimal climate grid cell resolution (OCGR) based on winter wheat (Triticum aestivum L) yield simulations in complex topographical zones (CTZ) and flat topographical zones (FTZ) in the Araucanía Region of Chile (37\%35' and $39^{\circ} 37^{\prime} \mathrm{S}-73^{\circ} 31^{\prime}$ and $\left.71.31^{\prime} \mathrm{W}\right)$. The OCGR was estimated from the simulated crop yield (CERES-DSSAT) using a semivariogram to compute the distance, which minimize yield differences with respect to its neighbors. Climate variables were obtained from DGF-PRECIS $(25 \mathrm{~km})$ downscaled to a fine resolution of $1 \mathrm{~km}$ through Precipitation characterization with Auto-Searched Orographic and Atmospheric (PCASOA). Climate variables were calibrated and validated from 56 in-situ meteorological stations between 1961 and 1991 and the yield was validated from field experiments. The crop simulation presented no significant differences (3.0 $\pm 0.3-3.0 \pm 0.1 \mathrm{Mg} \mathrm{ha}^{-1}$ ) compared to field experiments. Increasing the resolution improves the crop simulation reducing the RSME from 0.8 to $0.32 \mathrm{Mg} \mathrm{ha}^{-1} \mathrm{The}$ OCGR estimated averaged $<7 \mathrm{~km}$ for CTZ, whereas it was $>25 \mathrm{~km}$ for FTZ. Our approach can be applied for similar crops and complex topographical zones.
\end{abstract}

Keywords: Scale, crop simulation, downscaling, climate database

\section{Introduction}

Crop yield estimation using mesoscale (grid cell of 20-50 km) data (e.g. CRU; New et al., 1999; GCCP; Huffman et al., 1997; DGF-PRECIS, Fuenzalida et al., 2006) have been used to study local responses from crop simulation models (Hansen et al., 2006). Database from mesoscale models have also been used to feed crop simulation models and evaluate different management practices (irrigation protocols and dynamics of pest and diseases) (Cooley et al., 2005) and overall climate change impacts on agriculture (Jara, 2013; Tan and Shibasaky, 2003; White et al., 2011).

To capture the climate spatial heterogeneity for high resolution $(<1 \mathrm{~km})$ modelling is not an easy task, because we need a high resolution database. This is achieved when a dense network of meteorological 
stations (Mitchel and Jones, 2005), or high resolution climate grids $(\sim 1 \mathrm{~km})$ (Baron et al., 2005; Mearns et al., 2003; Tsvetsinskaya, 2003) are available. Only few studies have addressed the impact of high resolution climate grid cell on simulation crop yield (Angulo et al., 2013; Olesen et al., 2000). Most of them are performed in flat zones, and they are based on ground meteorological records and the spatial density is generated using interpolation techniques, where the unknown values need to be computed (Angulo et al., 2013).

Several downscaling techniques have been performed to improve the local crop response reducing the grid resolution (Daly, 1994; Guan et al, 2009; Wilby and Wigley, 1997). Downscaling produces important differences of climate output, and hence in modeled crop yield response (Baron et al., 2005; Mearns et al, 2003; Tsvetsinskaya, 2003). Mearns et al. (2003) reported in $25 \%$ decrease in spring rains, downscaling from $400 \mathrm{~km}$ to $50 \mathrm{~km}$ influencing negatively the yield and quality of wheat crop. Similar results were reported by Baron et al. (2005) in West Africa and Tsvetsinskaya (2003) in Southern USA. The grid cell resolution changes has been evaluated by dynamical models (e.g. WRF, MM5) with high number of computations and large numerical error (Von Hardenberg et al., 2007). The latter problem has been solved in part by topographic downscaling using multi-regression approach (Daly, 1994; Guan et al., 2009; Rupp et al., 2012). For example, the precipitation can be distributed from a low to high cell resolution by empirical functions based on topographical predictors (Grupta and Waimire, 1993). The most important topographical downscaling model is the Precipitation Characterization with Auto-Searched Orographic and Atmospheric effects (PCASOA) (Guan et al., 2009). This model includes a digital elevation model (DEM), where elevation, slope and aspects is regarded to improve spatial representation of climatic variables. Since the final scale resolution of topographical downscaling is $<1$ $\mathrm{km}$, the question regarding the optimum climate grid cell resolution (OCGR) that represents the spatial crop yield variability under different topographical conditions becomes relevant. The latter is the focus of the present study. The spatial variability of any continuous variable can be represented using a semivariogram (Hengl, 2007). The semivariogram is a plot where the $x$-axis is the sampling distance $(\mathrm{Km})$ from the $y$-axis variable measured from their neighbors. Thus, the $y$-axis is the variance of $y$ denoted by $[\gamma(h)]$ (Hengl, 2007). The $\gamma(h)$ rises as the distance increases up to a maximum, the sill, a plateau, which is reached at distance $h$, the range (Hengl, 2007). This technique can be used to estimate $h$ of the simulated crop yield to estimate OCGR influenced by topographical effects. Within the range $h$, the crop yield values are autocorrelated, thus any unknown yield point can be interpolated from their neighbors at any direction using the appropriated model. Beyond $h$, the crop yield variance is independent from their neighbors.

Chile has a mesoscale DGF-PRECIS climatic database at $25 \mathrm{~km}$ resolution (http://www.dgf.uchile. cl/PRECIS/, last accessed July 2013) for the entire country (Fuelzalida et al., 2006). In the present study, we developed a methodological tool to predict the OCGR, based on a crop yield simulation using high resolution PCASOA model database downscaled from DGF-PRECIS under different topographical conditions (flat topographical zones, FTZ and hilly side complexes topographical zones, CTZ) in the Araucanía Region of Chile.

The aims of the present study were: $i$ ) to quantify the impact of topographical downscaling (PCASOA, Guan et al., 2009) on low resolution database (DGFPRECIS) as climate input on a crop simulation model of winter wheat (Triticum aestivum L) (CERESDSSAT, 2008) and ii) to estimate the OCGR using a semivariogram of simulated crop yield in FTZ and CTZ in Araucanía Region of Chile. 


\section{Methodology}

\subsection{Study area}

The region under study corresponds to the Araucanía Region $\left(37^{\circ} 35^{\prime}\right.$ and $39^{\circ} 37^{\prime} \mathrm{S}-73^{\circ} 31^{\prime}$ and $\left.71.31^{\prime} \mathrm{W}\right)$ covering $67,500 \mathrm{~km}^{2}$. Climate is characterized by a dry season between December and March with rainfall between 50 and $70 \mathrm{~mm}$ per month, which corresponds to a Mediterranean climate. The wet season is from May to September with maximum rainfall of 220$270 \mathrm{~mm}$ per month. The mean annual precipitation is $1,200 \mathrm{~mm}$ (Rouanet, 1983). The warmest months are from December to February $\left(10^{\circ} \mathrm{C}\right.$ to $\left.27^{\circ} \mathrm{C}\right)$ and the coldest ones from June to August $\left(3^{\circ} \mathrm{C}\right.$ to $\left.8{ }^{\circ} \mathrm{C}\right)$ (Rouanet, 1983). The whole region is influenced by ENSO cycles (Montecinos and Aceituno, 2002), which produce an important interannual variability in precipitation and temperature (La Niña, dry-cold and El Niño, warm-wet phase, Grimm et al., 2000). The Araucanía Region presents important soil variability, mostly influenced by volcanic activity. According to Soil Survey Staff (2008) in the Region, there are several soils type; Andisols, Alfisols and Ultisols (CIREN-CORFO, 2002). The region presents the typical orographical pattern of central Chile. The Costal range (1,500 m.a.s.1.), called Cordillera de Nahuelbuta in the western side and Cordillera de los Andes in the eastern side (3,500 m.a.s.1.). From North to South, there is an intermediate depression with agriculture valleys of moderate height (Börgel et al., 1979) where most Chilean wheat grains produced (INE, 2007) (Figure 1).

\subsection{In-situ database}

We selected 56 meteorological stations located in the Region (Figure 1) with a complete rainfall records from 1961 to 1991 (see below), whereas a few stations (5) presented climate records such as photosynthetically active radiation (PAR) and temperature. Using the rule of decade continuous years or 15 years of noncontinuous precipitation records between 1961 and 1991, 10 selected stations were used to calibrate the mesoscale DGF-PRECIS database. These criteria were defined to include the records within Pacific Decadal Oscillation, which is the main source of climatic variability in the Region (Newman et al., 2003). The remaining 46 stations were used to validate the PCASOA model output (see section 2.4).

\subsection{Calibration and validation of DGF-PRECIS database}

The mesoscale database was used and it was obtained from PRECIS model, which was applied to the continental Chilean territory between 1961 and 1991 (Fuenzalida et al., 2006). DGF-PRECIS database was created in 2006 to simulate the impact of climate change from the dynamic downscaling at $25 \mathrm{~km}$ grid from HadCM3 model $(300 \mathrm{~km})$ (Fuenzalida et al., 2006). DGF-PRECIS dataset considered 42 climate variables including PAR, temperature, and rainfall. In this study we consider 108 pixels of $25 \mathrm{~km}$ each from DGF-PRECIS database. The simulated rainfall was validated by comparing the mean precipitation of each month with in-situ climatology records (1960-1991) for each of the ten selected meteorological stations. DGFPRECIS database underestimated the rainfall in winter and autumn, but overestimated this variable in summer and spring. Thus, the database was corrected by computing a monthly ratio of in-situ and modeled data. This value was multiplied by each monthly value of DGF-PRECIS. Therefore, a corrected monthly rainfall was used. Since temperature and solar radiation could not be validated using meteorological records, these variables were used directly from DGF-PRECIS database for crop modelling.

\subsection{Calibration and validation of PCASOA model}

The corrected DGF-PRECIS was downscaled from 25 $\mathrm{km}$ to $1 \mathrm{~km}$ using PCASOA model for projecting the rainfall (Guan et al., 2009). PCASOA is a statistical model based on multi-regression equation at $1 \mathrm{~km}$ of grid resolution (Guan et al., 2009) using topographic significant variables (coordinates, elevation, slope and aspect):

$$
\left.Y=b_{0}+b_{1} X f_{1}+b_{2} X f_{2}+b_{3} X f_{3}+\left(b_{4} X f_{4}+b_{5} X f_{5}\right) X f_{6}\right)
$$


where $\mathrm{Y}$ is the rainfall, $X f_{1}$ and $X f_{2}$ are the Easter and Northern coordinates respectively (in UTM projection corrected by the scale factor), $X f_{3}$ is the altitude (in $\mathrm{km}), X f_{4}$ is the sin of the aspect, $X f_{5}$ is the cosine of the aspect, $X f_{6}$ is the slope, and $\mathrm{b}_{0}-\mathrm{b}_{5}$ are coefficients. To run the PCASOA model we used: $i$ ) the corrected DGF-PRECIS database as ASCII list format with UTM projection coordinates and ii) DEM model in ASCII grid format and projected in the same geographical area. Detailed knowledge to run PCASOA model was also considered as indicated by Guan et al (2009). The DEM was obtained from the Global Topography (GTOPO30) project (Harding et al, 1999) for the Araucanía Region. This consists of 30 arc-second (about $1 \mathrm{~km}$ ) altitude maps from radar satellite records. The PCASOA was calibrated by fitting a multiple regression model using topography characteristics as independent variables with the corrected DGF-PRECIS rainfall grids as dependent variable. Thus, the model was fitted to the result obtained by the equation for each climate grid in the time serie, to generate 1-km rainfall. Only the significant topographical variables $(p<0.05)$ were considered for the parameterization of the equations. The output PCASOA model was the rainfall grid downscaled at $1 \mathrm{~km}$, affected by significant topographical variables. Finally, the PCASOA model was over 125 pixels (25 x $25 \mathrm{~km}$ ) using the corrected database from DGFPRECIS, giving a total of 67,500 fine resolution grid $<$ $1 \mathrm{~km}$ per month.

The downscaled rainfall records were validated by comparing the climate average of the remaining 46 meteorological stations records. The validation showed a positive bias through the year, except for summer season. However, this bias was less than $15 \%$ in the growing season (data not shown). This error should be assessed to the crop modeling impact, but the error is comparable with other models validated under similar topography zone (Diaz et al., 2010).

The standard spatial deviation of elevation index (SSDE, Biteuw et al., 2009) was used to separate the studied area in two large homogeneous topographical zones: $i$ ) the flat topographical zone, FTZ including intermediate depression valleys and flat agricultural areas and ii) the complex topography zone, CTZ, namely hilly-side valleys and both mountain ranges. The SSDE consists of a $12.5 \mathrm{~km}$ radius area with SSDE $<100$ m.a.s.l. for FTZ and > 100 m.a.s.l. for CTZ. The FTZ, $21,875 \mathrm{~km}^{2}$ and the CTZ covered an area of $22,500 \mathrm{~km}^{2}$ including 21 and 36 meteorological stations respectively. The remaining $23,125 \mathrm{~km}^{2}$ represented the sea and high montains. The selected FTZ were associated to two stations: Maquehue (38 $46^{\prime}$ S $-72^{\circ} 38^{\prime}$ W) at the Experimental Farm Station of Universidad de La Frontera and Puerto Saavedra ( $38^{\circ} 47^{\prime}$ S- $\left.73^{\circ} 24^{\prime} \mathrm{W}\right)$. The CTZ were associated to Angol (37'58' S $-72^{\circ} 50^{\prime}$ W) and Cunco (38 55'S -72'2' W) (Figure 1).

\subsection{Validation of crop simulation model}

Crop simulation was performed by CERES crop model included in the supported decision system (DSSAT, V.4.0). This model is the most used for estimating the climate change impact on cropping responses (Meza et al., 2008; Wo et al., 2013). The model allows changes in several parameters such as $\mathrm{CO}_{2}$ concentration, fertilization, irrigation schedule, and the use of different varieties. CERES model requires a daily weather (maximum and minimum temperature, rainfall and PAR radiation), soil dataset, management conditions, and genetic-crop parameters (Jones et al., 2003). The corrected DGF-PRECIS database was downscaled on monthly terms, but we required climate on daily basis. A stochastic weather generator CLIMGEN (Campbell, 1990) was used. To estimate the yield variability, we used the rainfall output dataset from PCASOA model and PAR and temperatures from corrected DGF-PRECIS database. Thus, we produced 50 synthetic years of weather data.

In the present study, the selected variety was the generic DSSAT winter wheat defined by seven coefficients: vernalization days (60 days), photoperiod effect ( 75 days), grain filing duration $\left(500{ }^{\circ} \mathrm{C}\right.$ degree days base $10{ }^{\circ} \mathrm{C}$ ), kernel number (30 units $\left.\mathrm{kg}^{-1}\right)$, kernel average weight under optimum condition (40 mg), stem and spike dry weight at maturity $(1.5 \mathrm{~g})$, and phyllochron interval $\left(95^{\circ} \mathrm{C}\right.$ degree days base $\left.10^{\circ} \mathrm{C}\right)$. 


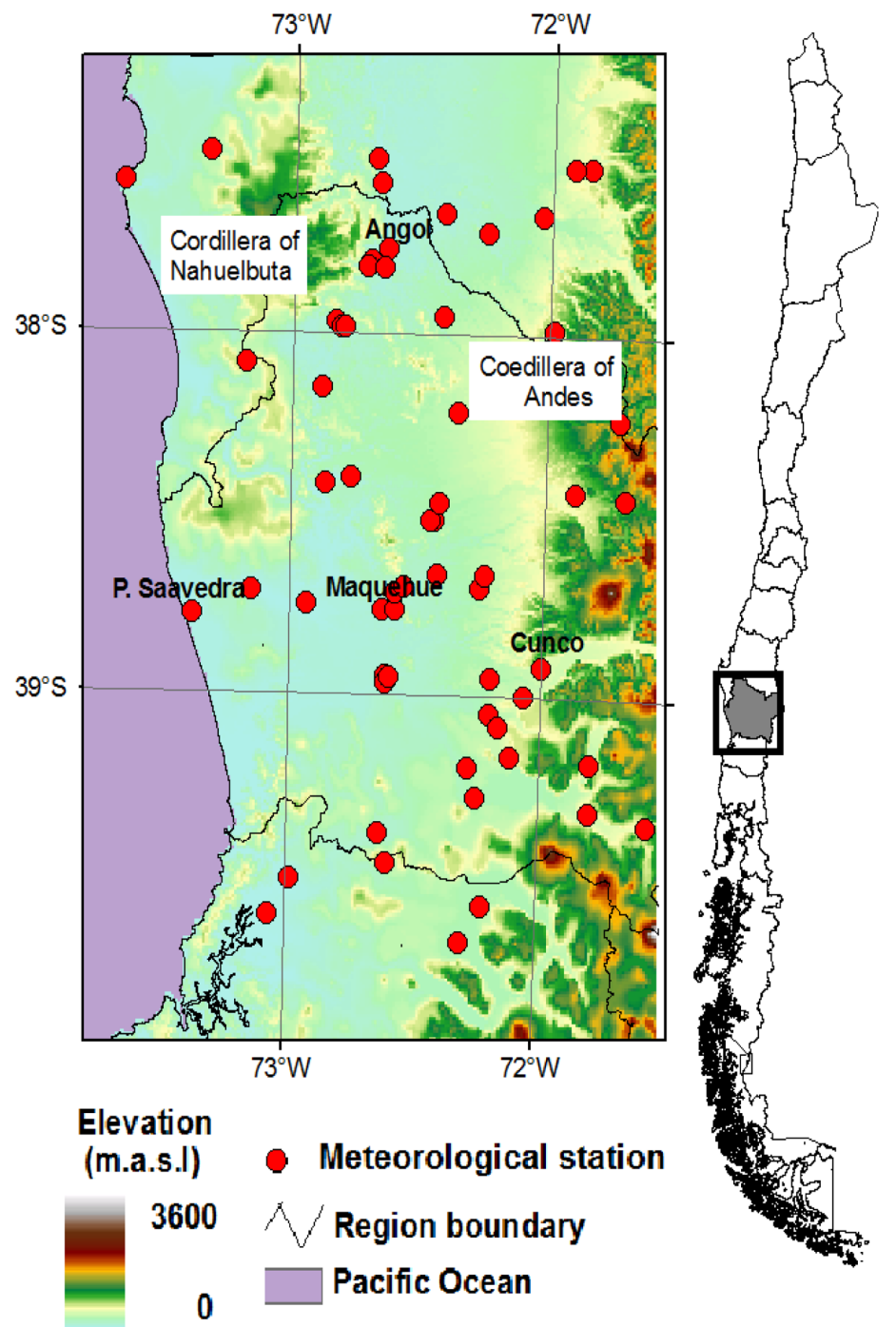

Figure 1. Araucanía Region, (Chile) showing 56 meteorological stations covering an area of $44,375 \mathrm{~km}^{2}$. The rest $23,125 \mathrm{~km}^{2}$ of the total Region area is the sea and high mountains areas. The station located close to the region borders were used to avoid boundary effects. The names inserted show the zones used for estimating the optimal grid cell resolution. 
These coefficients correspond to European winter wheat in DSSAT system. The crop model management parameters were defined based on the current values used by the farmers in the Region (sowing in May, 250 plants $\mathrm{m}^{-2}$ and row spacing $16 \mathrm{~cm}$ ). Since the present study focused on determining the effect of climate grid cell resolution based on the simulated grain yield, we fixed soil data obtained from the generic soil default in DSSAT (IB00000002). For simulation, phosphorous and other nutrients in soils were not limiting, except nitrogen $(\mathrm{N})$ which was not considered (Angulo et al, 2013; Palusso et al., 2011).

CERES model output was validated by comparing the observed winter wheat yield in two season years, 2008 and 2009, from experiments carried out across the Region. One experiment was performed at the Experimental Farm Station in Maquehue (Universidad de La Frontera) using winter wheat (cv. Kumpa), seeded under unlimited phosphorous and other nutrients, except $\mathrm{N}$. Five levels of $\mathrm{N}$ fertilization (urea), including a control without $\mathrm{N}$ were applied. Other experiments (1988-2007) of non-N fertilizer control winter wheat across the region were also regarded (Campillo et al., 2010; Campillo et al., 2007; Rouanet, 1994). The comparison between simulated and observed yields was performed using a parwaise sample t-test (see below).

To assess the impact of the scale change of climate variables as affected by the topographical conditions on the simulated crop yield, we compared the difference between simulated yield using in-situ rainfall records and those obtained from corrected DGF-PRECIS and PCASOA model. These comparisons were performed using a pairwise sample t-test, the root squared mean error (RSME), and a Q-plot. These comparisons were computed based on the difference between in-situ simulation and the low and high resolution simulations.

\subsection{Optimal climate grid cells resolution}

To estimate the OCGR we used a spatial technique, the semivariogram to compute the range $h$, the distance where the simulated winter wheat yield variability can be predicted. We simulated the yield on high resolution cell $(1 \mathrm{~km})$ nested within a low resolution cell $(25 \mathrm{~km})$ in a typical year as 1970 (i.e. a year close to the historical average and monthly distribution of rainfall). Although the semivariogram techniques can be computed considering the neighbor in all directions (omnidirectional semivariogram), in this study the directions were selected based on orographic dominance. We considered a longitudinal transect from West to East and latitudinal transect from North to South in the CTZ and FTZ, respectively. Thus, four simulated crop yield semivariograms were computed, two for each FTZ and CTZ using ARC-GIS 9.1 software (Redland California, USA).

\subsection{Data analysis}

The t-paired test was conducted using EXCEL 2003 in the module Data Analysis. All tests were at 0.05 level.

\section{Results}

\subsection{Crop model validation and spatial resolution impact}

The simulated wheat yield (1961-1991) ranged from $2.8 \pm 0.2 \mathrm{Mg} \mathrm{ha}^{-1}$ to $3.3 \pm 0.2 \mathrm{Mg} \mathrm{ha}^{-1}$, whereas in the field experiments, it ranged from $2.5 \pm 0.5 \mathrm{Mg} \mathrm{ha}^{-1}$ to $3.5 \pm 0.3 \mathrm{Mg} \mathrm{ha}^{-1}$ and they were typical from low yield crop in the crop rotation when no $\mathrm{N}$ is added. There were no significant differences within zones and between zones, although the crop yield were slightly lower in Vilcún (Figure 2).

The average error values of simulated crop yield using the PCASOA or corrected DGF-PRECIS database, above or below simulated crop yield values was obatained using in-situ data records from the 46 meteorological stations is shown in Figure 3. There were significant differences in the error between simulated crop yields using high resolution or low resolution database relative to in-situ ground simulation. 

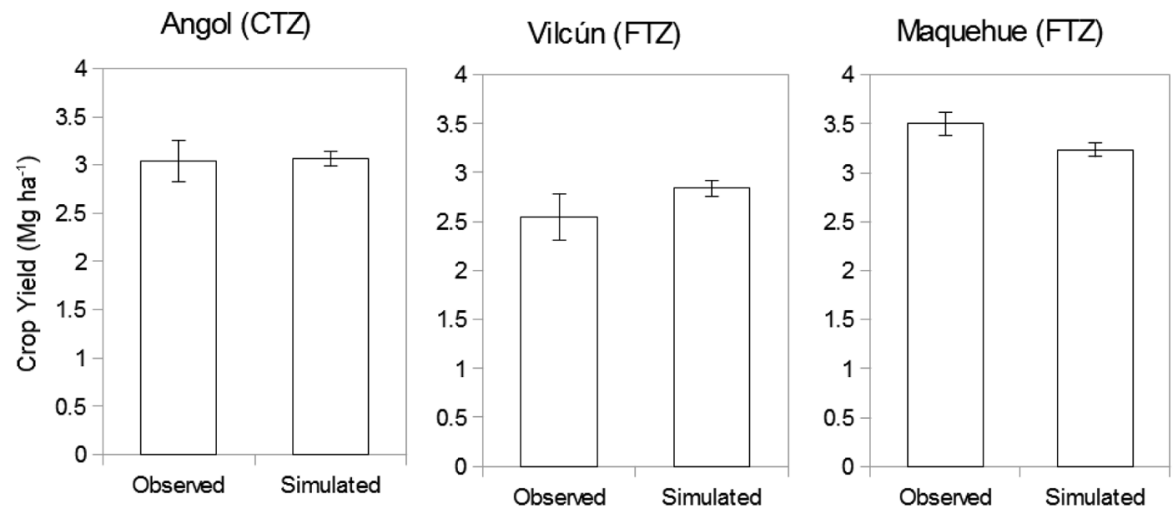

Figure 2. Average of observed (1988-2007) winter wheat yield field experiments from Vilcún (n=6), Maquehue $(\mathrm{n}=14)$ and Angol $(\mathrm{n}=15)$ (see Figure 1) representing the flat topography zones (FTZ) and complex topography zones (CTZ) in the Araucanía Region as compared with the simulated (DSSAT) winter wheat yield average (1961-1991) at the same locations. Bars represent the standard error of the mean.

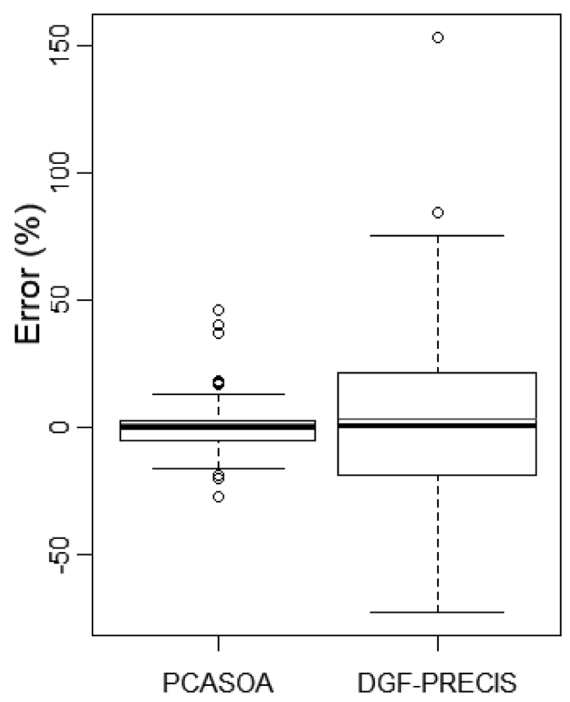

Figure 3. Boxplot error, i.e. the percentage of yield crop relative to the simulated (DSSAT) winter wheat yield in a typical year 1970 (a year close to the historical average) and monthly distribution of rainfall) by PCASOA high resolution $(<1 \mathrm{~km})$ climate output database and corrected DGF-PRECIS low resolution $(25 \mathrm{~km})$ climate output database relative to in-situ climate records simulation from 46 meteorological stations (1961 and 1991) in the Araucanía Region of Chile. Grey line in each box shows the mean error and black line shows the median error. 
The error from high resolution database ranged from $-27 \%$ to $42 \%$ of the ground simulation, whereas for low resolution database it ranged from $-72 \%$ to $153 \%$, doubling PCASOA yield errors. In fact, the RSME of PCASOA is less than that of DGF-PRECIS (0.319 and $0.768 \mathrm{Mg} \mathrm{ha}^{-1}$ respectively).

The simulated yield in the FTZ and CTZ using the high or low resolution database and the ground records data from the stations by zones is presented in Figure 4. The absolute amount of winter wheat yield was different only in CTZ $(p<0.05)$ (Figure 4b). High resolution database showed less error than low resolution database improving the crop simulation in about a $50 \%$ (RSME $0.257 \mathrm{Mg} \mathrm{ha}^{-1}$ for PCASOA and 0.719 $\mathrm{Mg} \mathrm{ha}^{-1}$ for DGF-PRECIS). In the FTZ, high resolution simulation showed the lowest variability, whereas low resolution showed the highest. However, the simulated mean yield values were similar among all databases (high resolution $2.24 \mathrm{Mg} \mathrm{ha}^{-1}$, low resolution $2.25 \mathrm{Mg} \mathrm{ha}^{-1}$, and in-situ data $2.26 \mathrm{Mg}$ ha $^{-1}$ ). In contrast, in CTZ the simulated yield using in-situ and PCASOA database was $1.97 \mathrm{Mg} \mathrm{ha}^{-1}$ and $2.09 \mathrm{Mg} \mathrm{ha}^{-1}$, respectively, whereas the variability for low resolution in the CTZ was highest $(2.20 \mathrm{Mg}$ ha $\left.{ }^{1}\right)$. Comparing the error of high resolution and low resolution database, high resolution database showed less error in both zones (-27 to $46 \%$ in FTZ and -8 to $40 \%$ in CTZ compared with low resolution database ( -72 to $75 \%$ and -51 to $153 \%$ ) (Figure $4 \mathrm{c}$ and $4 d$ ).

\subsection{Optimal climate grid cell resolution}

The semivariogram of the crop yield variability to estimate the OCGR for the FTZ is shown in Figure 5 and for CTZ in Figure 6. Both, FTZ and CTZ showed a spatial autocorrelation within the distance $h$, hence spatial variability could be predicted by a semivariograms using the default model provided by ARC-GIS 9.1 software. In fact, all zones showed Moran's indexes close to one, which indicates that the database was autocorrelated $(p<0.01)$. Some semivariograms reached a stationary (steady-state) variability showing the maximum distance $h$ at $<25$ $\mathrm{km}$ (Figure 6). In those cases where the steady state was not reached, we assume that $h$ was $>25 \mathrm{~km}$. For example, in the FTZ (Maquehue and P Saavedra), there was no range $h$ because the semivariogram did not reach a stationary yield either in North-South or East-West directions, suggesting a range $\geq 25 \mathrm{~km}$ (Figure 5). In the latter case we consider the OCGR beyond the mesocale $25 \mathrm{~km}$ resolution grids. In contrast the OCGR in Cunco (CTZ) was estimated $<25 \mathrm{~km}$, depending on the directions North-South or West-East (Figure 6). In Angol, $h$ was $15 \mathrm{~km}$ from North to South and $17 \mathrm{~km}$ from West to East (Figure 6). The last two cases are explained by the topography. In Cunco, there is a valley crossing the cell at West-East direction, dividing the area in hillside and valley. In Angol, the Nahuelbuta Mountains present an elevation just on the northern zone, which increases the rainfall with respect to the southern zones.

\section{Discussion}

In the present study we assumed that downscaling climate low resolution rainfall database for crop model is useful to predict an OCGR. We hypothesized that the spatial resolution of the simulated crop yield can be computed, which in turn represents the optimal grid cell resolution $<1 \mathrm{~km}$ database under flat and complex-topography scenarios. For this purpose, we used a semivariogram technique. This methodology could be generalizated to any crop and zone, being an intersting tool for assessing the climate effect on crop systems. Also, OCGR is not only useful for crop research, but also for climate grids, whish are commonly used in several applications related with forest activity, wild live, human health and water suply, which can use similar approach to the technique proposed in the present study.

In contrast to the approach used in the presente study, as far as we know, there are few papers estimating OCGR using up-scaling interpolation from the 


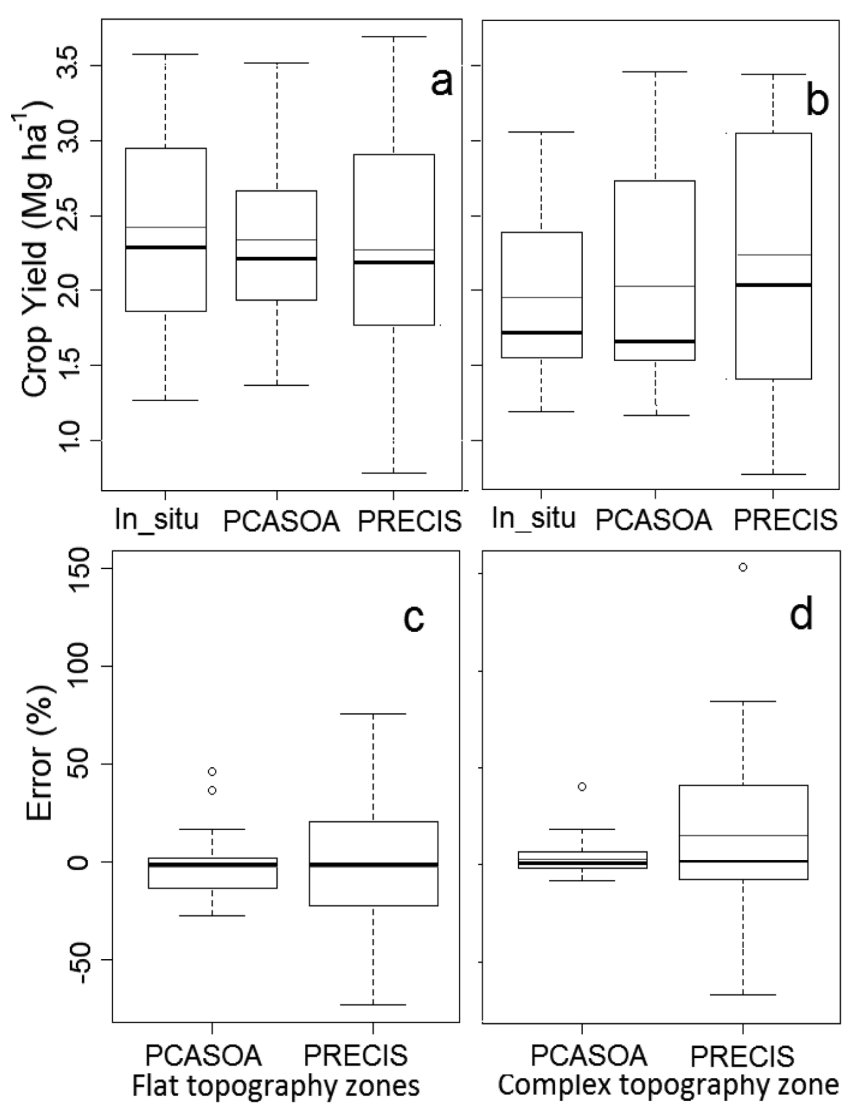

Figure 4. Boxplot of (a-b) absolute simulated (DSSAT) winter wheat yield from in-situ climate records from 46 meteorological stations (1961 and 1991) in Araucanía Region and (c-d) relative error of simulated crop yield of typical year 1970 a year close to the historical average by PCASOA high resolution $(<1 \mathrm{~km})$ output database and DGFPRECIS low resolution $(25 \mathrm{~km})$ climate database relative to in-situ climate records. The gray lines in each box show the mean of yield or the mean of errors and black lines, the median of these values.

meteorological record dataset (Olesen et al., 2000, Wong and Asseng, 2006) and no papers using spatial resolution and topographical features for OCGR estimation. That OCGR estimation was possible because the high resolution climate grid obtained by PCASOA model, which improved significantly the simulated crop yield $(50 \%)$ introducing the topographical effects in the CTZ. This contrasts with the results obtained by Olesen et al. (2000), who reported the spatial crop variability in Denmark at $10 \mathrm{~km}$ grid. This by Olesen et al. (2000), who reported the spatial crop variability in Denmark at $10 \mathrm{~km}$ grid. This effect could not be explained by the climate grid cell resolution, since there was no correlation between the climate and yield variability. Angulo et al. (2013) studied the spatial crop yield variability in Norway and they reported yield differences of $4 \%$ when the scale resolution changed from in-situ data to $20 \mathrm{~km}$ grid. 
They used several models (including DSSAT) for simulating crop yield and they observed that the resolution scale explained less the variability than the crop model, because the study was performed in the flat agricultural areas. In contrast to the results of Olesen et al. (2000) and Angulo et al. (2013), the present results indicated a clear relationship between the topographic variables and the impact of climate resolution on crop yield simulation (Figure 4).

Although up-scaling is the unique reference for comparing our results, both approaches have different sources of errors. It expected that both approaches can present different yield responses. Up-scaling depends on the interpolation method and the climate record density. The spatial resolution technique proposed here depends on climate modeling quality and agriculture feasibility, mainly limited by topographical considerations. We think that the present technique is more suitable than up-scaling from synthetic scenarios based on climate grids (e.g. climate change and climate cycles) or where interpolation methods are unreliable due to lack of data, and/or low spatial autocorrelation in FTZ.
From our results, a poor correlation $\left(\mathrm{r}^{2}=0.30, p<\right.$ $0.01)$ between high rainfall of in-situ records data ( $>$ $2,000 \mathrm{~mm}$ ) and crop yield was observed, while the opposite was true $\left(\mathrm{r}^{2}=0.71, p<0.01\right)$ at low rainfall $(<2,000 \mathrm{~mm})$. This could be explained because high rainfall improves the crop growing conditions, reducing the effect of climate variability. In fact, when rainfall exceeds $2,000 \mathrm{~mm}$, soil moisture is not limiting factor for crop growth and precipitation is not related to yield variability (Wong and Aseng, 2006). This result supported our hypothesis, the topography influences on OCGR estimation, particularly in CTZ. Therefore, from an operative point of view, the OCGR can be well estimated in dry years to increase the sensitivity of the crop simulation response to climate input to assess the climate effect on crop yield. On the other hand, in the present study we shows that mesoescale $(25 \mathrm{~km})$ database is a suitable climate grid resolution for representing the spatial crop-yield variability in flat zone in winter wheat. Our result validate the conclusions of several works based on mesoescale climate models performed in the flat zones (e.g. Cooley et al., 2005; Meza et al., 2008; Palusso et al., 2011).
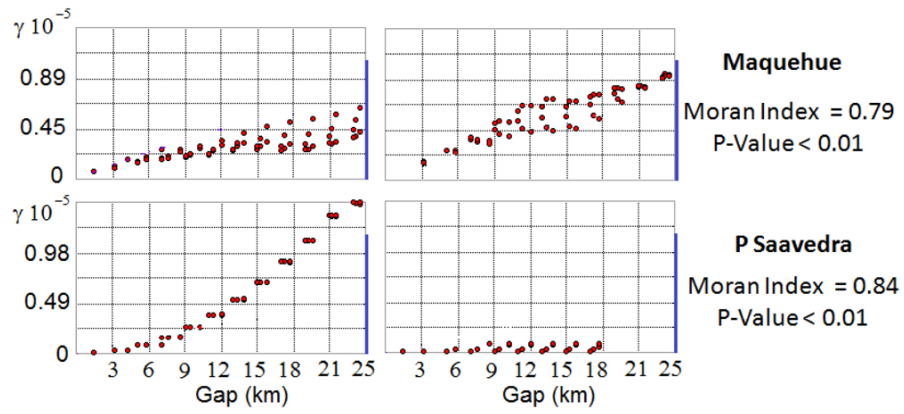

Figure 5. Spatial variability of simulated (DSSAT) winter wheat yield representing the flat topography zones (FTZ) in the Araucanía Region. Left semivariogram is North-South direction and right semivariograms is EastWest direction. Moran probability index $(0=$ non autocorrelation and $1=$ full autocorrelation $)$. Vertical line shows the estimated the distance range $h$ to calculate the optimal climate grid cell resolution (OCGR). 
However, CTZ require higher climate grid resolution for representing it spatial crop variability. Although the most important productive zones of wheat are locate on FTZ, CTZ is a valuables agricultural land with microclimates and where small (subsistence) farmers are located. These zones are very vulnerable to climate damage by extreme events (presently unknown because of the lack of climate records).
Thus, downscaling for the study type conducted here should be focused on CTZ, including hillyside mountains areas. Climate in this area can be modeled using improved input grids such as OCGR calculated using our approach. In addition, our approach can be used for examining the microclimate at high resolution climate dataset for public polices makers in the near future.
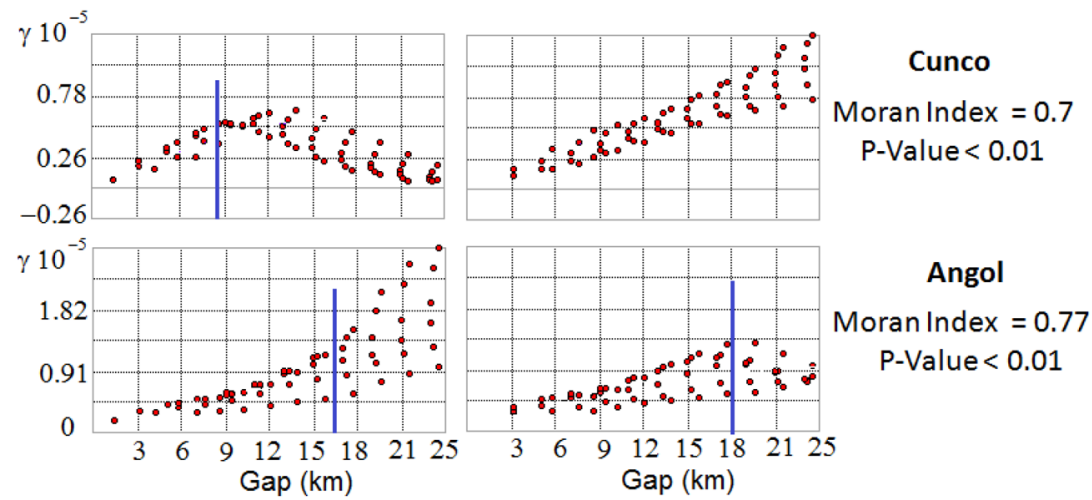

Figure 6. Spatial variability of simulated (DSSAT) winter wheat yield representing the complexes topography zones (CTZ) in the Araucanía Region. Left semivariogram is North-South direction and right semivariograms is East-West direction. Moran probability index $(0=$ non autocorrelation and $1=$ full autocorrelation $)$. Vertical line shows the estimated distance range $h$ to calculate the optimal climate grid cell resolution (OCGR).

\section{Conclusion}

In this study we provide an approach for selecting the optimal scale linking climate grids with crop modeling to assess the impact of high resolution downscaling technique on crop simulations to calculate the optimal climate grid cell resolution (OCGR). of (DSSAT) winter wheat yield in Araucanía Region. We show that downscaling using PCSOA model improves the crop model performance in about $50 \%$, reducing the RSME from 0.778 to $0.319 \mathrm{Mg} \mathrm{ha}^{-1}$. These effects depend on the topographical conditions. In flat topographical zones there are no significant differences in the crop yield simulated with high resolution $(<1 \mathrm{~km})$ or mesoscale resolution $(<25 \mathrm{~km})$ database, whereas in complexes topographical (hilly side and mountains) zones these differences were highly significant. In the Araucanía Region in the flat zones, the optimal climate grid cell resolution was $>25 \mathrm{~km}$, while in complexes zones, it was between 8 and $17 \mathrm{~km}$. The optimal climate grid cell resolution estimation was also affected by total rainfall and topography variables (altitude, aspect and slope) providing a clear assessment to a simple estimation of climate grid resolution for optimal crop yield. The broad implication of our findings is: In flat zones, climate we do not require downscaling from mesoscale models database, whereas in hilly-side and complex topography zones downscaling to simulate the optimal crop yield is required. 


\section{Acknowledgements}

The original dataset was obtained from Estudio de Variabilidad Climática en Chile para el Siglo XXI (PBCT ACT-19, http://www.dgf.uchile.cl/PRECIS/), performed by Departamento de Geofísica (DGF), de la Universidad de Chile, and funded by Comisión Nacional de Medio Ambiente (CONAMA). We are highly indebted from Direction General de Aguas (DGA, Chile) and Armada de Chile for facilitate the in-situ meteorological data. We acknowledge FONDEF DO6I 1100 project for the financial support and feld experiment. We acknowledge to $\mathrm{Mr}$. Aureliano Troncoso for their technical assistant in the field experiments and data manipulation. R. Orrego would like to thank CONICYT for the grant that supported doctoral work $\mathrm{N}^{\circ} 21090443$ ). This research was partially supported by the supercomputing infrastructure of the NLHPC (ECM-02) at Centro de Modelación y Computación Científica at Universidad de La Frontera CMCC-UFRO. We acknowledge the two anonymous reviewers for the effort and time devoted to this manuscript.

\section{References}

Angulo, C., Rötter, R., Trnka, M., Pirttioja, N., Gaiser, T., Hlavinka, P., Ewert, F. 2013. Characteristic 'fingerprints' of crop model responses to weather input data at different spatial resolutions. European Journal of Agronomy. 49, 104-114.

Baron, C., Sultan, B., Balme, M., Sarr, B., Traore, S., Lebel, T., Janicot, S., Dingkuhn., M. 2005. From GCM grid cell to agricultural plot: scale issues affecting modeling of climate impact. Philosophical Transactions of Royal Society B. 360, 2095-2108.

Biteuw, M., Gebremichael, M., Hirpa, F.A., Gebrewubet, Y.M., Seleshi, Y., Girma, Y. 2009. On the local-scale spatial variability of daily summer rainfall in the humid and complex terrain of the Blue Nile: observational evidence. Hydrological Processes. 23, 3670-3674.

Börgel, R. 1986. Geografía de Chile, IX Región de La Araucanía. Santiago de Chile: Instituto Geográfico Militar de Chile.

Campbell, G.S. 1990. ClimGen, climatic data generador. Washington State University.

Campillo, R., Jobet, C., Undurraga, P. 2007. Optimización de la fertilización nitrogenada para trigo de alto potencial de rendimiento en andisoles de la Región de la Araucanía, CHILE. Chilean Journal of Agricultural Research. 67, 3: 281-291

Campillo, R., Jobet, C., Undurraga, P. 2010. Effects of nitrogen on productivity, grain quality, and optimal nitrogen rates in winter wheat cv. Kumpa-INIA in andisols of southern Chile. Chilean Journal of Agricultural Research. 70, 1:122-13

CIREN-CORFO. 2002. Descripciones de suelos, materiales y suelos. Estudio agroecológico IX Región. Centro de Información de Recursos Naturales (CIREN). Corporación de Fomento de la Producción (CORFO). Santiago, Chile

Cooley, H.S., Riley, W.J., Torn, M.S., He, Y. 2005. Impact of agricultural practice on regional climate in a coupled land surface mesoscale model. Journal of Geophysical Research: Atmospheres (1984-2012), 110.D3

Daly, C., Neilson, R.P., Phillips, D.L. 1994. A statisticaltopographic model for mapping climatological precipitation over mountainous terrain. Journal of Applied Meteorology. 33, 140-158.

Diaz, D., Morales, L., Castellaro, G., Neira, R. 2010. Topoclimatic Modeling of Thermopluviometric Variables for the Bío Bío and La Araucanía Regions, Chile. Chilean Journal of Agricultura Research. 70, 4: 604-615. 
Dirección General de Aguas (DGA). 2012. Red hidrometeorológica. Disponible en http://www. arcgis.com/apps/OnePane/basicviewer/index.ht $\mathrm{ml}$ ?appid=d508beb3a88f43d28c17a8ec9fac5ef0. It visited at May 5st of 2012.

Fuenzalida, H.M., Falvey, M., Rojas, P., Aceituno, R. Garreaud. 2006. Estudio de la variabilidad climática en Chile para el siglo XXI. Informe para CONAMA. $71 \mathrm{p}$.

Guan, H., Wilson, J., Xie, H. 2009. A clusteroptimizing regression-based approach for precipitation spatial downscaling in mountainous terrain. Journal of Hydrology. 375, 578-588.

Grimm, A.M., Barros, V.R., Doyle, M.E. 2000. Climate variability in southern South America associated with El Niño and La Niña events. Journal of climate. 13, 35-58.

Grupta, V., Waymire, E. 1993. A statistical analysis of mesoscale rainfall as a random cascade. Journal of Applied Meteorology. 32, 251-267.

Hansen, J., Challinor, A., Ines, A., Wheeler, T., Moron, V. 2006. Translating climate forecasts into agricultural terms: advances and challenges. Climate Research. 33, 27-41.

Harding, D., Dean, B. Gesch, C., Carabajal, C., Luthcke, S.B. 1999. Application Of The Shuttle Laser Altimeter In An Accuracy Assessment Of Gtopo30, A Global 1-Kilometer Digital Elevation Model. International Archives of Photogrammetry and Remote Sensing. 32, 81-85.

Hengl, T. 2007. A Practical Guide to Geostatistical Mapping of Environmental Variables. European Community Publication Office, Italy. 165 p.

Huffman, G., Adler, R., Arkin, P., Chang, A., Ferraro, R., Gruber, A., Janowiak, J., McNab, A., Rudolf, B., Schneider, U. 1997. The Global Precipitation Climatology Project (GPCP) Combined
Precipitation Dataset. Bulletin of the American Meteorological Society. 78, 5-20.

INE (Instituto Nacional de Estadísticas). 2010. InformeEconómico Regional. Available from: http://www.ine.cl/canales/chile_estadistico/ territorio/iner/iner.php.

Jara, V., Meza, F. J., Zaviezo, T., Chorbadjian, R. 2013. Climate change impacts on invasive potential of pink hibiscus mealybug, Maconellicoccus hirsutus (Green), in Chile. Climatic Change. 117,1-2, 305-317.

Jones, J., Hoogenboom, G., Porter, C., Boote, K., Batchelor, W., Hunt, L, Wilkens, J., Singh, U, Gijsman, A., Ritchie, J. 2003. The DSSAT cropping system model. European Journal of Agronomy. 18, 235- 265.

Mearns, L.O., Carbone, G., Doherty, R.M., Tsvetsinskaya, E., Mccarl, B.A., Adams, R.M., Mcdaniel, L. 2003. The Uncertainty due to Spatial Scale of Climate Scenarios in Integrated Assessments: An Example from U.S. Agricultura. Integrated Assessment. 4, 225-235.

Meza, F., Silva, D., Vigil., H. 2008. Climate change impacts on irrigated maize in Mediterranean climates: Evaluation of double cropping as an emerging adaptation Agricultural Systems. 98, 21-30.

Montecinos, A., Aceituno, P. 2003. Seasonality of the ENSO-Related Rainfall Variability in Central Chile and Associated Circulation Anomalies. Journal of Climate. 16, 281-296

New, M., Hulme, M., Jones, P. Representing twentieth-century space-time climate variability. 1999. Part I: Development of a 1961-90 mean monthly terrestrial climatology. Journal of Climate $12,829-856$.

Newman, M., Compo, G.P., Alexander, M. 2003. ENSO-forced variability of the Pacific Decadal Oscillation. Journal of Climate. 16, 3853-3857. 
Olesen, J., Bøcher, E., Jensen, T. 2000. Comparison of scale of climate and soil data for aggregating simulated yield of winter wheat in Denmark. Agriculture, Ecosystems and Environment. 82, 213-228.

Palusso, T., Kersebaum, K. C., Angulo, C., Hlavinka, P., Moriondo, M., Olesen, J. E., Patilf, R., Rugetg, F., Rumbaurc, C., Takáčh, J., Trnkad, M., Bindii, M., Çaldağj, B., Ewertc, F., Ferrisee, R., Mirschelb, W., Şaylanj, L., Šiškak, B., Röttera, R., Rötter, R. 2011. Simulation of winter wheat yield and its variability in different climates of Europe: a comparison of eight crop growth models. European Journal of Agronomy. 35, 103-114.

Rouanet, J.L., 1983. Clasificación agroclimática IX Región. Macroárea I. Investigación y Progreso Agropecuario. INIA Carillanca 2(4): 25-28.

Rouanet, J.L. 1994. Eficiencia fisiológica de uso de nitrógeno por cultivos anuales en futura agricultura sustentable. Agricultura Técnica. 54, 169-179.

Rupp, D., Licznar, P., Adamowski, W., Lésniewski, M. 2012. Multiplicative cascade models for fine spatial downscaling of rainfall: parameterization with rain gauge data. Hydrology and Earth System Science. 16, 671-684.

Survey Laboratory Staff. 1996. Soil survey laboratory methods manual. Soil Survey Investigations Report, vol. 42. USDA SCS, Washington DC, USA.
Tan, G., Shibasaki, R. 2003. Global estimation of crop productivity and the impacts of global warming by GIS and EPIC integration. Ecological Modelling. $168,357-370$.

Tan, G., Shibasaki, R. 2003. Global estimation of crop productivity and the impacts of global warming by GIS and EPIC integration. Ecological Modelling. $168,357-370$.

Tsvetsinskaya, E.A., Mearns, L.O., Mavromatis, T., Gao, W., Mcdaniel, L., Downton, M.W. 2003. The effect of spatial scale of climatic change scenarios on simulated Maize, Winter Wheat, and Rice production in the Southeastern United Status. Climatic Change. 60, 37-71.

Von Hardenberg, J., Ferraris, L., Rebora, N., Provenzale, A. 2007. Meteorological uncertainty and rainfall downscaling. Nonlinear Processes in Geophysics. 14, 193-199.

Wilby, R.L., Wigley, T.M.L. 1997. Downscaling general circulation model output: A review of methods and limitations, Progress in Physical Geography. 214, 530-548.

White, J., Hoogenboomb, G., Kimball B., Wall, G. 2011. Methodologies for simulating impacts of climate change on crop production. Field Crops Research. 124, 357-368.

Wong, M.T.F., Asseng, S. 2000. Determining the causes of spatial and temporal variability of wheat yields at sub-field scale using a new method of upscaling a crop model. Plant and Soil. 283, 1,2, 203-215. 